\title{
Comparison of linear functions to estimate growth performance and feed intake variations pattern in growing and finishing pigs in high ambient temperature
}

\author{
N. Lee' ${ }^{1}$, J. W. Choi ${ }^{2}$, H. S. Ko ${ }^{2}$, S. J. Ohh ${ }^{2}$, Y. H. Kim ${ }^{3}$, A. R. Jang' ${ }^{2}$ and J. S. Kim ${ }^{2, *}$ \\ ${ }^{1}$ College of Business Administration, Kangwon National University, \\ Chuncheon, 24341, Republic of Korea \\ ${ }^{2}$ College of Animal Life Sciences, Kangwon National University, \\ Chuncheon, 24341, Republic of Korea \\ ${ }^{3}$ Swine Division, National Institute of Animal Science, Rural Development Administration, \\ 114, Sinbang 1-gil, Seonghwan-eup, Seobuk-gu, Cheonan-si, \\ Chungcheongnam-do, 31000, Republic of Korea \\ *CorrespondingE-mail: kjs896@kangwon.ac.kr
}

Received November 15, 2018; Accepted April 17, 2019

\begin{abstract}
ABSTRAK
Suhu lingkungan yang tinggi (AT) adalah kendala utama pada efisiensi peternakan dalam produksi babi. Hasil penelitian yang dilaporkan menilai pengaruh ST tinggi pada kinerja babi sangat bervariasi, terutama pada babi dengan berat badan (BW) berbeda. Oleh karena itu, meta-analisis dari ISI Web of Science dan PubMed dioperasikan untuk menjelaskan variasi rata-rata asupan pakan harian (ADFI) dan rata-rata pertambahan bobot badan harian $(\mathrm{ADG})$ dalam laporan lintas literatur selama AT tinggi dalam pertumbuhan atau finishing babi. Babi dibagi menjadi tiga kategori BW sebagai LOW (46 hingga 65 $\mathrm{kg})$, MED $(65<$ hingga $85 \mathrm{~kg})$, dan HFH $(85<\mathrm{kg})$. Pengaruh nyata AT pada ADG diamati pada kategori LOW, MED dan HGH. Analisis ragam (Anova) untuk regresi linier berganda menunjukkan signifikansi hubungan linear antara kedua data $\mathrm{ADG}$ dan ADFI, dengan AT dan BW sebagai: $\mathrm{ADG}_{\mathrm{LOW}}=1260$ $19.9 * \mathrm{AT}+2.09 * \mathrm{BW}, \mathrm{ADG}_{\mathrm{MED}}=1546-22.5 * \mathrm{AT}-0.88 * \mathrm{~W}, \mathrm{ADG}_{\mathrm{HGH}}=1893-31.9 * \mathrm{AT}-2.40 * \mathrm{BW}, \mathrm{ADFI}_{\mathrm{LOW}}=$ $1756-35.0 * \mathrm{AT}+24.6 * \mathrm{BW}, \mathrm{ADFI}_{\mathrm{MED}}=2793-49.6 * \mathrm{AT}+12.5 * \mathrm{BW}$, dan $\mathrm{ADFIHGH}=4172-59.0 * \mathrm{AT}+$ $0.74 * \mathrm{BW}$. Pengaruh temperatur yang signifikan terhadap rasio penambahan: pakan (G: F) diamati pada kategori LOW dan HGH. Analisis regresi berganda mengungkapkan bukti tentang signifikansi tinggi hubungan linear antara G:F dan AT, yaitu G:F ${ }_{\text {Low }}=0,80+0,02 * \mathrm{AT}+0,02 * \mathrm{BW}, \mathrm{G}: \mathrm{F}$ MED $=0,95+$ $0,02 * \mathrm{AT}+0,02 * \mathrm{BW}$, dan $\mathrm{G}: \mathrm{F}_{\mathrm{HGH}}=0,78+0,05 * \mathrm{AT}+0,01 * \mathrm{BW}$. Hasil keseluruhan dari analisis model campuran menunjukkan bahwa interaksi yang signifikan antara BW dan AT mengindikasikan babi dalam kategori yang lebih berat memiliki G:F yang lebih rendah ketika suhu meningkat. Kesimpulannya, AT tinggi secara linear mengurangi ADG, ADFI, dan G:F dari babi tahap growing dan finishing.

Kata kunci: stress panas, babi masa growing, babi masa finishing, tampilan pertumbuhan, intake pakan
\end{abstract}

\begin{abstract}
High ambient temperature (AT) is a major constraint on efficiency of farming in pig production. Results of reported studies assessing the influences of high AT on pig performance are highly variable,
\end{abstract}


particularly in pigs with different body weight (BW). Therefore, a meta-analysis from ISI Web of Science and PubMed was operated to explain variations of average daily feed intake (ADFI) and average daily gain (ADG) in the reports across literatures during high AT in growing or finishing pigs. Pigs were divided to three BW categories as LOW (46 to $65 \mathrm{~kg}$ ), MED ( $65<$ to $85 \mathrm{~kg}$ ), and HGH ( $85<$ $\mathrm{kg}$ ). The significant effect of AT on ADG were observed in LOW, MED, and HGH categories. The analysis of variance (ANOVA) for multiple linear regression shows significance of linear relationships between both $\mathrm{ADG}$ and $\mathrm{ADFI}$, and $\mathrm{AT}$ and $\mathrm{BW}$ as: $\mathrm{ADG}_{\mathrm{LOW}}=1260-19.9 * \mathrm{AT}+2.09 * \mathrm{BW}, \mathrm{ADG}_{\mathrm{MED}}=1546-$ $22.5 * \mathrm{AT}-0.88 * \mathrm{~W}, \mathrm{ADG}_{\mathrm{HGH}}=1893-31.9 * \mathrm{AT}-2.40 * \mathrm{BW}, \mathrm{ADFI}_{\mathrm{LOW}}=1756-35.0 * \mathrm{AT}+24.6 * \mathrm{BW}, \mathrm{ADFI}_{\mathrm{MED}}=$ $2793-49.6 * \mathrm{AT}+12.5 * \mathrm{BW}$, and $\mathrm{ADFI}_{\mathrm{HGH}}=4172-59.0 * \mathrm{AT}+0.74 * \mathrm{BW}$. The significant effect of temperature on gain to feed ratio (G:F) was observed in LOW and HGH categories. The ANOVA for multiple regression revealed evidence on high significance of linear relationships between G:F and AT: G:F $=0.80+0.02 * \mathrm{AT}+0.02 * \mathrm{BW}, \mathrm{G}: \mathrm{F}_{\mathrm{MED}}=0.95+0.02 * \mathrm{AT}+0.02 * \mathrm{BW}$, and $\mathrm{G}_{\mathrm{HGH}}=0.78+0.05 * \mathrm{AT}+0.01 * \mathrm{BW}$. The overall results of mixed model analysis show that the significant interaction between $\mathrm{BW}$ and AT means that pigs in heavier category have lower G:F when temperature increases. In conclusion, high AT linearly decrease the ADG, ADFI, and G:F of growing and finishing pigs.

Keywords: Heat stress, growing pigs, finishing pigs, growth performance, feed intak

\section{INTRODUCTION}

In tropical and sub-tropical regions, farmers produce meat throughout the year, although the production rate is restricted to some extent in the hot seasons (Pearce et al., 2015). There is worldwide pressure concerning nutrition and efficiency of intensively managed swine farms due to global warming Mayorga et al. (2018). For many years, researchers have been studying the impact of heat stress on the performance of swine, including growing pigs (Pearce et al., 2014), finishing pigs (Johnson et al., 2015), and sows (Choi et al., 2018), and have found that high ambient temperature (AT) have adverse influences on productive and reproductive performance. An old reference also showed a 40 to $80 \mathrm{~g} / \mathrm{d}$ decrease in feed intake per degree Celsius in the range between 20 to $30^{\circ} \mathrm{C}$ (Le Dividich et al., 1998).

High temperatures is a major constraint on efficiency of farming in pig production. The capacity of animals is low to diminish body heat during high AT (Pearce et al., 2015; Cervantes et al., 2018). Therefore, the natural reaction of animals to reduce detrimental effects of heat stress and maintain constant body temperature is to decrease heat production from average daily feed intake (ADFI). The extent of decrease in voluntary feed intake may be related to the physiological condition, age, body weight (BW), and breed of pigs and the severity of heat stress. The lower growth performance is the main consequence of reduced ADFI. There is much information regarding the relationships between heat stress and swine ADFI or productivity, however, there is very little recent research in the literature regarding the extent of interaction between heat stress and ADFI.

The purpose of the present experiment was to evaluate the effects of high AT on ADFI in growing and finishing pigs.

\section{MATERIAL AND METHODS}

\section{Literature Search and database recording}

A detailed search of literatures from 2002 to 2017 was performed in the ISI Web of Science and PubMed by keywords and cited references in the published papers. Only the most recent literatures were considered to obtain the most appropriate data for the recent genetically improved races. Keywords included terms related to heat stress (high environmental temperature, high AT, hot environment, hot weather, etc), pigs (growing pigs, finishing pigs, swine), and performance (ADG and ADFI). The numerous literatures prepared by this search were filtered before statistical analysis. Studies on sows, gilts, and weaned pigs, or with short time exposure of heat stress, or conference proceedings without clarified results and conditions, or old literatures were eliminated before inclusion in the database. After the filtering step, the finalized database included 54 papers with 434 to 455 data points per trait (Table 1). The experimental temperatures were ranged from $18^{\circ} \mathrm{C}$ to $36^{\circ} \mathrm{C}$. We also divided the $\mathrm{BW}$ in 3 categories: light $\mathrm{BW}$ pigs (LOW; 46 to $65 \mathrm{~kg}$ ), medium BW pigs (MED, $>65$ to $85 \mathrm{~kg}$ ), 
Table 1. Feed Ingredient Composition and Nutrition Content of Experimental Feed

\begin{tabular}{|c|c|c|c|c|c|c|}
\hline Variables & $\begin{array}{l}\text { No. of } \\
\text { studies }\end{array}$ & $\begin{array}{c}\text { No. of } \\
\text { observations }\end{array}$ & Mean & SD & Minimum & Maximum \\
\hline \multicolumn{7}{|l|}{ BW46-65 kg } \\
\hline Average temperature ${ }^{\circ} \mathrm{C}$ & 30 & 118 & 23.1 & 3.74 & 18 & 36 \\
\hline Daily range ${ }^{\circ} \mathrm{C}$ & 3 & 19 & 4.74 & 5.13 & 0 & 10 \\
\hline Relative humidity (\%) & 1 & 4 & 67.5 & 0 & 67.5 & 67.5 \\
\hline DE (Kcal) & 4 & 27 & 3476 & 455 & 3042 & 4411 \\
\hline ME (Kcal) & 19 & 61 & 2877 & 1211 & 3 & 3596 \\
\hline NE (Kcal) & 14 & 52 & 1751 & 1023 & 2.24 & 2651 \\
\hline BW (kg) & 28 & 117 & 53.7 & 6.55 & 46.1 & 65 \\
\hline ADFI (g) & 30 & 119 & 2264 & 345 & 1198 & 2870 \\
\hline ADFI (g/kg BW) & 17 & 98 & 41.8 & 5.0 & 29.3 & 49.6 \\
\hline $\mathrm{ADG}(\mathrm{g})$ & 30 & 119 & 913 & 123 & 355 & 1206 \\
\hline F.G & 30 & 119 & 2.50 & 0.34 & 2.01 & 3.51 \\
\hline \multicolumn{7}{|l|}{$\mathrm{BW}>65-85 \mathrm{~kg}$} \\
\hline Average temperature ${ }^{\circ} \mathrm{C}$ & 28 & 147 & 22.8 & 3.40 & 18 & 31.4 \\
\hline Daily range ${ }^{\circ} \mathrm{C}$ & 11 & 46 & 2.26 & 3.69 & 0 & 10 \\
\hline Relative humidity... & 2 & 4 & 63.9 & 4.50 & 60 & 67.8 \\
\hline DE (Kcal) & 7 & 29 & 3135 & 1158 & 13.4 & 4297 \\
\hline ME (Kcal) & 17 & 92 & 3380 & 137 & 3107 & 3605 \\
\hline NE (Kcal) & 6 & 52 & 2365 & 160 & 2151 & 2575 \\
\hline BW (kg) & 28 & 147 & 78.2 & 4.91 & 65.5 & 84.95 \\
\hline $\operatorname{ADFI}(\mathrm{g})$ & 28 & 147 & 2641 & 457 & 1271 & 3534 \\
\hline ADFI (g/kg BW) & 28 & 147 & 33.8 & 5.79 & 15.4 & 47.1 \\
\hline $\mathrm{ADG}(\mathrm{g})$ & 28 & 147 & 965 & 110 & 590 & 1190 \\
\hline F.G & 28 & 147 & 2.75 & 0.46 & 1.33 & 4.73 \\
\hline \multicolumn{7}{|l|}{$\mathrm{BW}>85 \mathrm{~kg}$} \\
\hline Average temperature ${ }^{\circ} \mathrm{C}$ & 40 & 189 & 22.8 & 3.27 & 18 & 32.2 \\
\hline Daily range ${ }^{\circ} \mathrm{C}$ & 10 & 47 & 0.60 & 2.08 & 0 & 10 \\
\hline Relative humidity... & 3 & 25 & 65.7 & 3.45 & 60 & 67.8 \\
\hline DE (Kcal) & 6 & 35 & 3378 & 458 & 2806 & 4408 \\
\hline ME (Kcal) & 26 & 107 & 3389 & 152 & 2990 & 3650 \\
\hline NE (Kcal) & 9 & 49 & 2382 & 105 & 2100 & 2579 \\
\hline $\mathrm{BW}(\mathrm{kg})$ & 40 & 189 & 107 & 17.1 & 85.62 & 186 \\
\hline ADFI (g) & 40 & 189 & 2904 & 411 & 1850 & 3887 \\
\hline ADFI (g/kg BW) & 37 & 185 & 27.6 & 5.12 & 13.0 & 45.2 \\
\hline ADG (g) & 40 & 189 & 908 & 157 & 535 & 1357 \\
\hline F.G & 40 & 189 & 3.25 & 0.49 & 2.19 & 4.63 \\
\hline
\end{tabular}

SD, standard deviation; BW, body weight; DE, digestible energy, ME, metabolizable energy; NE, net energy; ADFI, average daily feed intake; ADG, average daily gain; G:F, gain to feed ratio. 
and heavy BW pigs ( $\mathrm{HGH} ;>85 \mathrm{~kg})$. To maintain an adequate number of reports, it was not possible to increase the number of categories.

\section{Statistical Analysis}

All the statistical analyses of the filtered database were conducted with the $\mathrm{R}$ software package (R Core Team, 2013). We conducted multiple linear regression analysis for each of the three BW categories and for the whole category in order to evaluate and compare the effects of the AT and BW on the production performances and ADFI of pigs. Regression models were estimated for prediction of each of the three response variables, $A D G, A D F I$, and $G: F$, where ADG represents the production performance, ADFI represents the feed intake of pigs, and G:F represents the production efficiency. The predictors of the multiple linear regression models were the average daily AT in Celsius and the BW of the pigs in $\mathrm{kg}$. Summary statistics of the response variables and the predictors are presented in Table 1.
Multiple linear regression models were fitted to the data by the ordinary least squares estimation method. In Tables 2, 3, and 4, we presented the results of the estimated regression models for each of the three categories and the whole category. The prediction model for each category included the AT and BW as predictors, and it did not include their interaction term because the interaction term did not yield statistically significant coefficient estimates. On the other hand, the prediction model for the whole category included the interaction term together with the AT and BW because it yielded statistically significant coefficient estimates.

\section{RESULTS}

\section{Average Daily Gain}

The results of the meta-analysis for the response variable ADG is presented in Table 2 . The corresponding ADG values for intercepts were $1260,1546,1893$, and 1178 for LOW, MED, $\mathrm{HGH}$, and overall respectively. The significant

Table 2. Multiple Linear Regression Models for Prediction of the Average Daily Gain (g/d) in Different Ambient Temperature (AT) and Weight Categories of Pigs

\begin{tabular}{|c|c|c|c|c|c|c|c|c|c|c|}
\hline $\begin{array}{l}\text { Weight } \\
\text { (kg) }\end{array}$ & $\begin{array}{c}\text { No of } \\
\text { Observations }\end{array}$ & $\begin{array}{l}\text { Independent } \\
\text { Variable }\end{array}$ & Estimates & SE & p-value & RMSE & $\begin{array}{l}\text { Multiple } \\
\text { R-squared }\end{array}$ & $\begin{array}{l}\text { Adjusted } \\
\text { R-squared }\end{array}$ & $\begin{array}{c}\text { F- } \\
\text { statistic }\end{array}$ & $\begin{array}{c}\mathrm{p}- \\
\text { value }\end{array}$ \\
\hline \multirow[t]{3}{*}{$46-65$} & 116 & intercept & 1262 & 89 & $<0.01$ & 99.7 & 0.35 & 0.34 & 30.1 & $<0.01$ \\
\hline & & $\mathrm{AT}$ & -19.86 & 2.56 & $<0.01$ & & & & & \\
\hline & & BW & 2.09 & 1.47 & 0.16 & & & & & \\
\hline \multirow[t]{3}{*}{$55-85$} & 147 & intercept & 1546 & 121.9 & $<0.01$ & 79.7 & 0.48 & 0.47 & 65.3 & $<0.01$ \\
\hline & & AT & -22.5 & 1.98 & $<0.01$ & & & & & \\
\hline & & $\mathrm{BW}$ & -0.88 & 1.37 & 0.52 & & & & & \\
\hline \multirow[t]{3}{*}{$>85$} & 189 & intercept & 1893 & 74.9 & $<0.01$ & 108.7 & 0.52 & 0.51 & 99.5 & $<0.01$ \\
\hline & & AT & -31.9 & 2.44 & $<0.01$ & & & & & \\
\hline & & BW & -2.40 & 0.47 & $<0.01$ & & & & & \\
\hline \multirow[t]{4}{*}{ Overall } & 452 & intercept & 1178 & 109.2 & $<0.01$ & 102.7 & 0.44 & 0.43 & 115.5 & $<0.01$ \\
\hline & & AT & -8.03 & 4.73 & 0.09 & & & & & \\
\hline & & BW & 3.99 & 1.27 & $<0.01$ & & & & & \\
\hline & & AT $\times$ BW & -0.21 & 0.05 & $<0.01$ & & & & & \\
\hline
\end{tabular}


Table 3. Multiple Linear Regression Models for Prediction of the Average Daily Feed Intake (g/d) in Different Ambient Temperature (AT) and Weight Categories of Pigs

\begin{tabular}{|c|c|c|c|c|c|c|c|c|c|c|}
\hline $\begin{array}{l}\text { Weight } \\
\text { (kg) }\end{array}$ & $\begin{array}{c}\text { No of } \\
\text { Observations }\end{array}$ & $\begin{array}{l}\text { Independent } \\
\text { Variable }\end{array}$ & Estimates & SE & $\mathrm{p}$-value & RMSE & $\begin{array}{l}\text { Multiple } \\
\text { R-squared }\end{array}$ & $\begin{array}{l}\text { Adjusted } \\
\text { R-squared }\end{array}$ & $\begin{array}{c}\text { F- } \\
\text { statistic }\end{array}$ & $\begin{array}{c}\text { p- } \\
\text { value }\end{array}$ \\
\hline \multirow[t]{3}{*}{$46-65$} & 116 & intercept & 1756 & 261 & $<0.01$ & 292 & 0.29 & 0.27 & 22.8 & $<0.01$ \\
\hline & & AT & -34.99 & 7.50 & $<0.01$ & & & & & \\
\hline & & $\mathrm{BW}$ & 24.60 & 4.30 & $<0.01$ & & & & & \\
\hline \multirow[t]{3}{*}{$55-85$} & 147 & intercept & 2793 & 634 & $<0.01$ & 415 & 0.17 & 0.16 & 14.6 & $<0.01$ \\
\hline & & AT & -49.6 & 10.3 & $<0.01$ & & & & & \\
\hline & & BW & 12.5 & 7.14 & 0.086 & & & & & \\
\hline \multirow[t]{3}{*}{$>85$} & 189 & intercept & 4172 & 249 & $<0.01$ & 361 & 0.22 & 0.21 & 26.5 & $<0.01$ \\
\hline & & AT & -59.0 & 8.1 & $<0.01$ & & & & & \\
\hline & & BW & -0.74 & 1.55 & 0.063 & & & & & \\
\hline \multirow[t]{4}{*}{ Overall } & 452 & intercept & 22.49 & 409 & $<0.01$ & 385 & 0.36 & 0.43 & 85.7 & $<0.01$ \\
\hline & & AT & -17.3 & 17.7 & 0.032 & & & & & \\
\hline & & BW & 18.1 & 4.75 & $<0.01$ & & & & & \\
\hline & & AT x BW & -0.37 & 0.21 & 0.070 & & & & & \\
\hline
\end{tabular}

effect of temperature on ADG were observed in LOW, MED, and HGH categories, however, the effect of weight on ADG in the weight categories was not affected by changing the temperature. The analysis of variance (ANOVA) for multiple linear regression shows significance of linear relationships between temperature and $\mathrm{ADG}$ $\left(\mathrm{P}_{\text {LOw }}<0.01, \quad \mathrm{P}_{\mathrm{MED}}=0.03 ; \quad \mathrm{P}_{\mathrm{HGH}}<0.01 ;\right.$ $\left.\mathrm{P}_{\text {OVERALL }}<0.01\right)$. The overall results of the mixed model analysis (Table 2) show the significant interaction between temperature and $\mathrm{BW}(\mathrm{P}<$ $0.01)$ means that pigs in heavier category are more sensitive to the increased temperature compared with pigs in lighter category. According to the Table 2, the representation of different weight categories seems to be an appropriate way of reducing data variance due to the significant effect and interaction of weight in overall ADG to minimize loss of information. The estimation of covariance components, SE, and RMSE are presented in Table 2. The RMSE adjusted for ADG effect was bigger for the HGH compared with the MED and LOW. The linear relationship between temperature and ADG determined in growing pigs is shown in Figure 1. In this figure, an apparent variation of ADG was shown and ADG decreased as temperature increased. The residual plot indicated no evidence of linear bias prediction for ADFI model (Figure 2). An equation for predicting $\mathrm{ADG}$ in growing pigs that included temperature and weight as independent variables was developed using the weight information in different categories:

$\mathrm{ADG}_{\mathrm{LOW}}=1260-19.9 * \mathrm{~T}+2.09 * \mathrm{~W}, \mathrm{ADG}_{\mathrm{MED}}=1546-$ $22.5 * \mathrm{~T}-0.88 * \mathrm{~W}$, and $\mathrm{ADG}_{\mathrm{HGH}}=1893-31.9 * \mathrm{~T}-$

\section{$2.40 * \mathrm{~W}$}

\section{Voluntary Feed Intake}

The list of significant main effects and interactions for ADFI is presented in Table 3. The corresponding ADFI values for intercepts were 1756, 2793, and 4172 for LOW, MED, and HGH respectively. Although the significant effect of weight on ADFI was observed in LOW category, 
Table 3. Multiple Linear Regression Models for Prediction of the Gain to Feed Ratio in Different Ambient Temperature (AT) and Weight Categories of Pigs

\begin{tabular}{|c|c|c|c|c|c|c|c|c|c|c|}
\hline $\begin{array}{c}\text { Weight } \\
(\mathrm{kg})\end{array}$ & $\begin{array}{c}\text { No of } \\
\text { Observations }\end{array}$ & $\begin{array}{l}\text { Independent } \\
\text { Variable }\end{array}$ & Estimates & $\mathrm{SE}$ & $p$-value & RMSE & $\begin{array}{l}\text { Multiple } \\
\text { R-squared }\end{array}$ & $\begin{array}{l}\text { Adjusted } \\
\text { R-squared }\end{array}$ & $\begin{array}{c}\text { F- } \\
\text { statistic }\end{array}$ & $\begin{array}{c}\mathrm{p}- \\
\text { value }\end{array}$ \\
\hline \multirow[t]{3}{*}{$46-65$} & 116 & intercept & 0.80 & 0.26 & $<0.01$ & 0.30 & 0.27 & 0.26 & 20.9 & $<0.01$ \\
\hline & & AT & 0.02 & 0.01 & $<0.01$ & & & & & \\
\hline & & BW & 0.02 & 0.00 & $<0.01$ & & & & & \\
\hline \multirow[t]{3}{*}{$55-85$} & 147 & intercept & 0.95 & 0.68 & 0.17 & 0.45 & 0.05 & 0.04 & 3.7 & 0.03 \\
\hline & & AT & 0.02 & 0.01 & 0.07 & & & & & \\
\hline & & BW & 0.02 & 0.01 & 0.03 & & & & & \\
\hline \multirow[t]{3}{*}{$>85$} & 189 & intercept & 0.78 & 0.28 & 0.01 & 0.40 & 0.31 & 0.03 & 40.9 & $<0.01$ \\
\hline & & AT & 0.05 & 0.01 & $<0.01$ & & & & & \\
\hline & & BW & 0.01 & 0.00 & $<0.01$ & & & & & \\
\hline \multirow[t]{4}{*}{ Overall } & 452 & intercept & 1.78 & 0.42 & $<0.01$ & 0.40 & 0.47 & 0.46 & 130.3 & $<0.01$ \\
\hline & & AT & 0.00 & 0.02 & 0.84 & & & & & \\
\hline & & BW & 0.00 & 0.00 & 0.45 & & & & & \\
\hline & & AT $x$ BW & 0.00 & 0.00 & 0.03 & & & & & \\
\hline
\end{tabular}

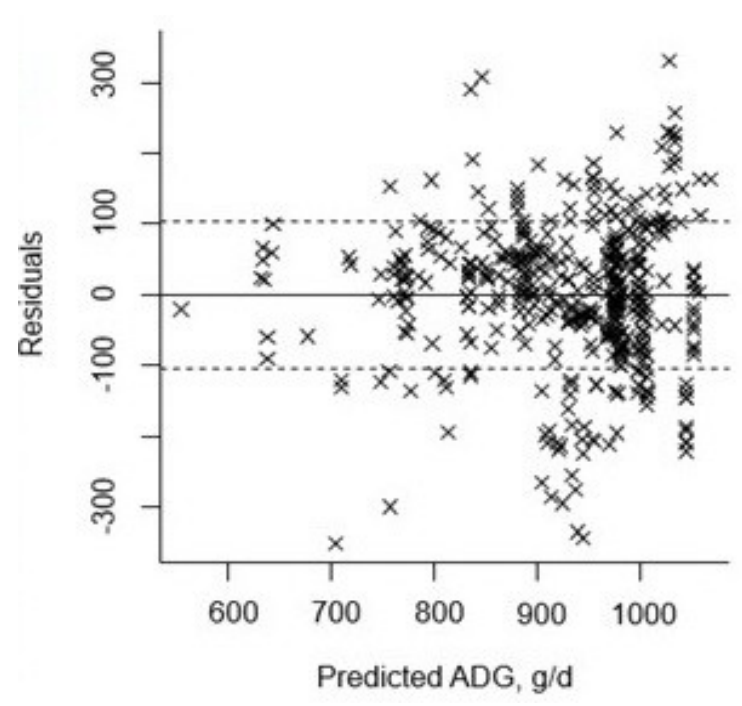

Figure 1. Plot of Residuals against Predicted Average Daily Gain from the Mixed Model Analysis

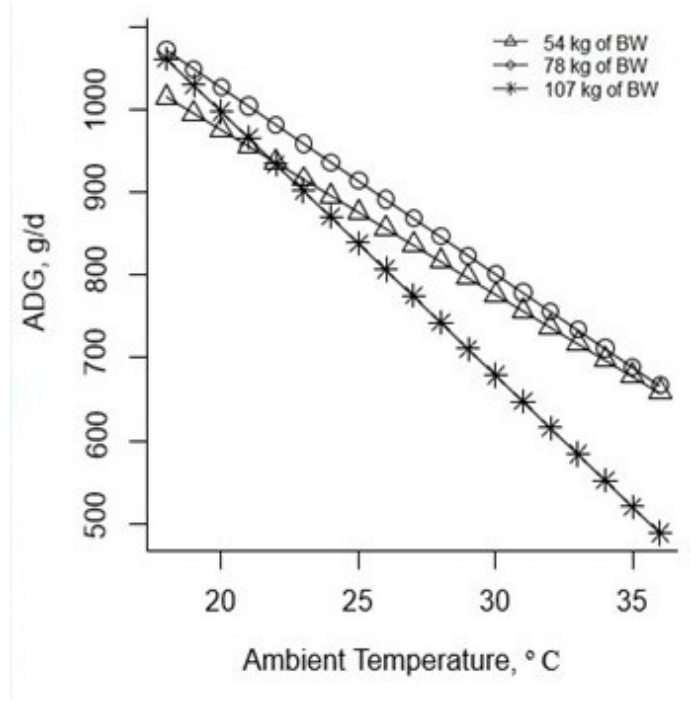

Figure 2. Effect of Ambient Temperature on Average Daily Gain in Different Weight Categories of Growing and Finishing Gigs 
neither significant ADFI differences in MED group nor within HGH group were found. The ANOVA for multiple linear regression indicates significance of linear relationships between temperature and ADFI $\left(\mathrm{P}_{\text {LOW }}<0.01, \mathrm{P}_{\text {MED }}<0.01\right.$; $\left.\mathrm{P}_{\text {HGH }}<0.01 ; \mathrm{P}_{\text {OVERALL }}<0.01\right)$. Based on the mixed model analysis results (Table 3 ), the insignificant interaction between temperature and $\mathrm{BW}(\mathrm{P}=$ 0.07) means that pigs have the same sensitivity in high AT. The estimation of covariance components, SE, and RMSE are presented in Table 3. The RMSE adjusted for ADFI effect was smaller for the LOW compared with the MED and HGH. Figure 3 indicated uncorrected ADFI vs temperature plot. In this figure, an apparent variation of ADFI was shown. In ADFI model, there was no evidence of any linear prediction bias in residual plot (Figure 4). An equation for predicting ADFI in growing pigs that included temperature and weight as independent variables was developed using the weight information in different categories:

$\mathrm{ADFI}_{\mathrm{LOW}}=1756-35.0 * \mathrm{~T}+24.6 * \mathrm{~W}, \mathrm{ADFI}_{\mathrm{MED}}=$ $2793-49.6^{*} \mathrm{~T}+12.5^{*} \mathrm{~W}$, and $\mathrm{ADFI}_{\mathrm{HGH}}=4172$ $59.0 * \mathrm{~T}+0.74 * \mathrm{~W}$

\section{Gain to Feed Ratio}

The results of the meta-analysis for the response variable G:F is presented in Table 4. The corresponding ADG values for intercepts were

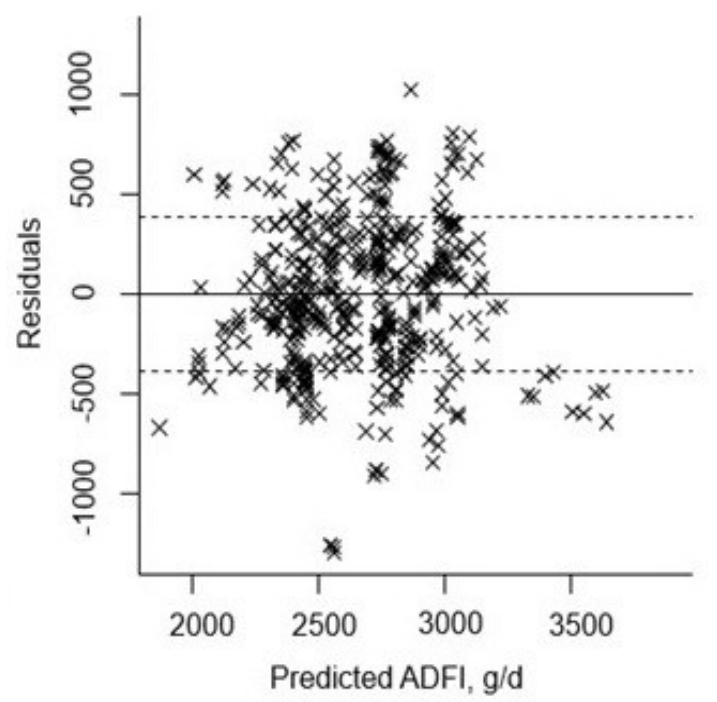

Figure 3. Plot of Residuals against Predicted Average Daily Feed Intake from the Mixed Model Analysis
$0.80,0.95,0.78$, and 1.78 for LOW, MED, HGH, and overall respectively. The significant effect of temperature on G:F were observed in LOW and $\mathrm{HGH}$ categories. Moreover, the weight in the weight categories affected the G:F in different temperature. The ANOVA for multiple linear regression revealed evidence on significance of linear relationships between $\mathrm{G}: \mathrm{F}$ and temperature $\left(\mathrm{P}_{\text {LOW }}<0.01, \quad \mathrm{P}_{\text {MED }}=0.03 ; \quad \mathrm{P}_{\mathrm{HGH}}<0.01\right.$; $\left.\mathrm{P}_{\text {OVERALL }}<0.01\right)$. The overall results of mixed model analysis show that the significant interaction between BW categories and temperature $(\mathrm{P}=0.03)$ on $\mathrm{G}: \mathrm{F}$ means that pigs in heavier category have lower G:F when temperature increases. According to the Table 4, the representation of different weight categories seems to be an appropriate way of reducing data variance due to the significant effect and interaction of weight in overall G:F. The estimation of covariance components, SE, and RMSE are presented in Table 4. The RMSE adjusted for G:F effect was lowest for the LOW. The linear relationship between temperature and $\mathrm{G}: \mathrm{F}$ determined in growing pigs is shown in Figure 5. The residual plot indicated no linear bias prediction for model G:F (Figure 6). An equation for predicting $\mathrm{G}: \mathrm{F}$ in growing pigs that included temperature and weight as independent variables was developed using the weight information in different categories:

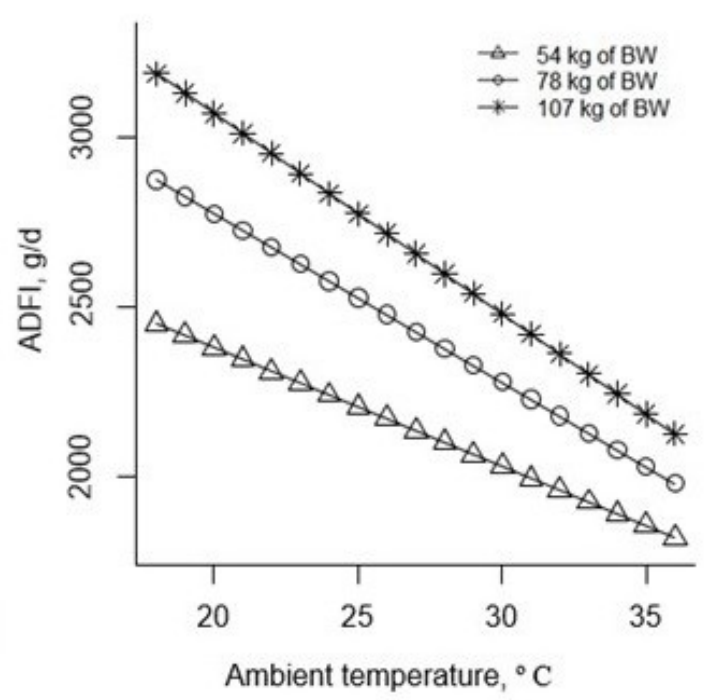

Figure 4. Effect of Ambient Temperature on Average Daily Feed Intake in Different Weight Categories of Growing and Finishing pigs 


$$
\begin{array}{lll}
\mathrm{G}: \mathrm{F}_{\mathrm{LOW}}= & 0.80+0.02 * \mathrm{~T}+0.02 * \mathrm{~W}, & \mathrm{G}: \mathrm{F}_{\mathrm{MED}}= \\
0.95+0.02 * \mathrm{~T}+0.02 * \mathrm{~W}, & \text { and } & \mathrm{G}_{\mathrm{HGH}}= \\
0.78+0.05 * \mathrm{~T}+0.01 * \mathrm{~W} & &
\end{array}
$$

\section{DISCUSSION}

The linear depression in ADG is in line with temperature evaluation systems adopting linear decrease in ADG or G:F with decreased in feed intake (NRC, 2012). Cervantes et al. (2018) suggested that the decline in ADG is proportional to the inverse of feed intake. The extent of growth depression depends on temperature level (Mayorga et al., 2018; Santos et al., 2018). Based on mixed model estimation for the ADG, the influence of enhanced temperature on ADG from 20 to $35^{\circ} \mathrm{C}$ is 1006 and $528 \mathrm{~g} / \mathrm{d}$ in finishing pigs in $\mathrm{HGH}$ group. The ADG of pigs in LOW and MED categories is almost 1.5 -fold greater at pigs in $\mathrm{HGH}$ category in $35^{\circ} \mathrm{C}$ temperature. In LOW category, the requirement of energy to optimize growth performance is higher than the ad libitum total energy intake, however, younger pigs can tolerate higher temperature better than older pigs (Renaudeau et al., 2011). Consequently, the decreased ADFI under hot AT negatively affect growth performance. The extent of decrease in ADG in this study is higher than older references (Hyun et al., 1998).

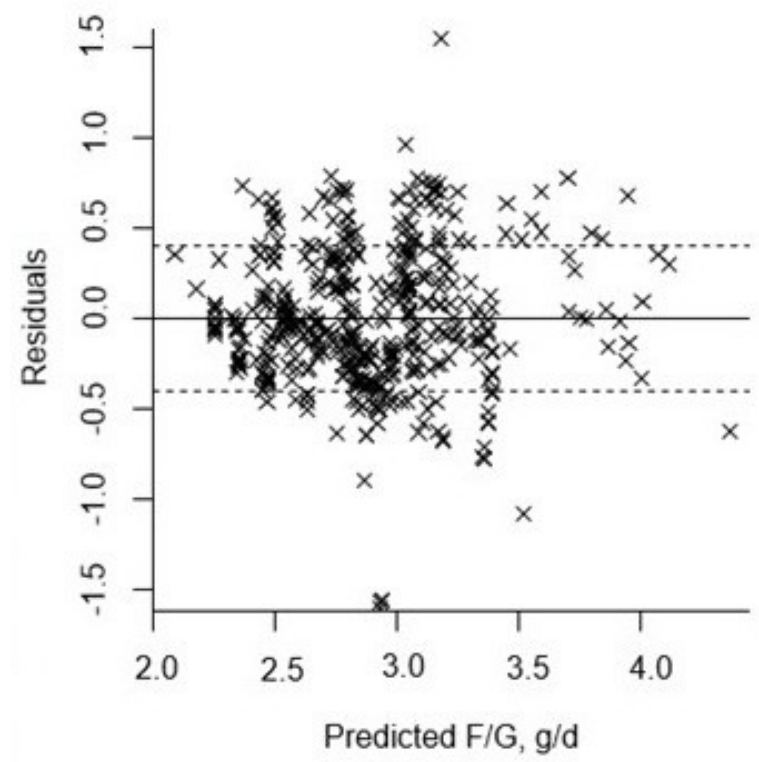

Figure 5. Plot of Residuals against Predicted Gain to Feed Ratio fromDaily Feed Intake from the Mixed Model Analysis
The effect of heat stress in pigs depends on several factors. The genetic selection in growing pigs, for which selection has favored growth performance and lean growth, the recent species are much less tolerant to heat stress than the traditional species (Hermesch et al., 2015). The higher heat production because of possibly greater ADFI may contribute to more severe effects of AT on ADG and G:F. The maintenance requirements of pigs are different based on the race, and lower in Large White pigs compared with synthetic line pigs because of the differences in metabolically active organs such as lean mass and viscera (Noblet et al., 1999). The consideration of the variance heterogeneity will produce more robust estimators, whose distributions will be closer to normal distributions.

Linear function was found the most suitable method to evaluate the variations of data of ADFI. This function allow selection on early ADFI with a smaller bias. Therefore, this quantitative linear analysis has shown an accurate model to explain the observed ADFI within each weight category. Regarding the differences between the result of this study and the older literatures, it seems that is not clear to precisely predict the future results according to the results of this study. Studies investigating the temperature effect on ADFI are difficult to conduct in pigs. A wide range in feed intake and growth performance cannot be

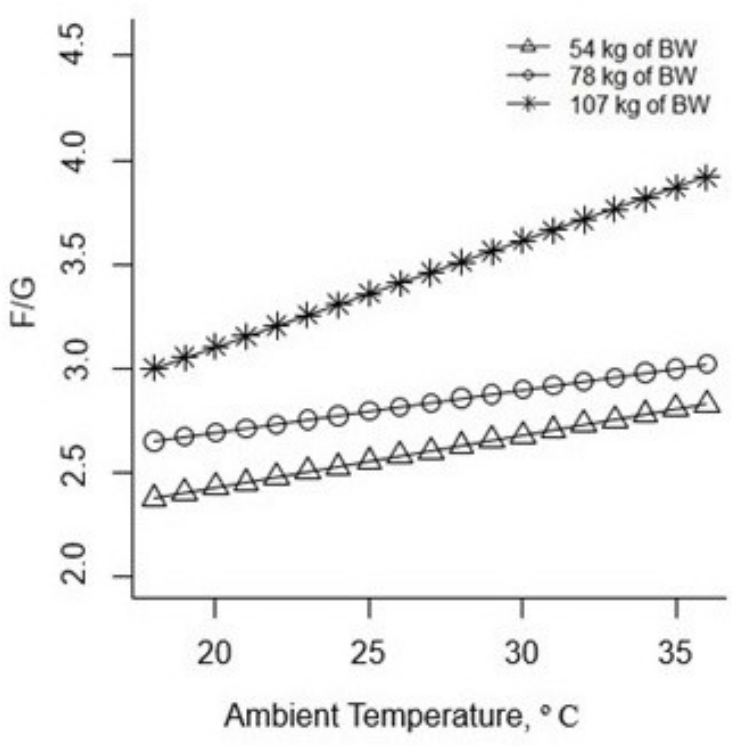

Figure 6. Effect of Ambient Temperature on Gain to Feed Ratio in Different Weight Categories of Growing and Finishing pigs 
achieved without confounding effects such as stage of growth, changes in environment, humidity, and particularly feed quality since the requirement of animals is different when temperature varies. As shown in NRC (2012), a different dietary requirements are suggested for pigs with the same weight but in different temperature. Furthermore, the ADFI depressions within a single study are mostly not large enough to show quantitative differences, particularly deviations from linearity, where the depressions in ADFI and the interactions between feed intake and diet composition are difficult to detect in different temperatures. Therefore, a regression analysis with the gathered information from different studies can be beneficial. However, there are many unidentified factors that can affect the meta-analysis result. There are various studies showing that the dietary energy level changes ADFI (Cottrell et al., 2015; Ghassemi Nejad et al., 2015, Choi et al., 2018). In the present study, along with ADFI, the metabolisable energy and net energy of diets were considered but finally were removed because of insignificant effects. The insignificant effects of diet energy levels can be due to the insufficient number of studies with dietary NE and ME information among the chosen papers in this meta-analysis or a small range of the dietary energy content. In agreement with this result, Renaudeau et al. (2011) reported that in their meta-analysis, there were quantitative relationships between ADFI and increased temperature. They also showed the large difference in the ADFI in different temperature may be related to factors such as animal sanitary status, climatic factors other than temperature, and animal performance. Interestingly, our analysis showed that heavier pigs are more sensitive to high AT because of sharper slopes in decreasing feed intake as temperature increased. For a pigs with an average of $107 \mathrm{~kg} \mathrm{BW}$, values of the partial derivative ADFI at 20 and $35^{\circ} \mathrm{C}$ were 3121 and $1901 \mathrm{~g}$ per day, respectively. In this view, the extent to which temperature influences the change in ADFI is largely depends on the temperature, as found in previous research (Renaudeau et al., 2011; Cervantes et al., 2018; Santos et al., 2018). The greater effects on temperature on ADFI in heavier pigs can be due to their natural key mechanism to minimal heat production by decreasing ADFI (Collin et al., 2001), particularly when temperature increases to above the upper limit of their thermoneutral zone.

\section{CONCLUSION}

High AT negatively affects the ADG, ADFI, and G:F in growing and finishing pigs, particularly heavier finishing pigs. The extent of decrease in the ADG and ADFI in the recent reports are higher than old reports. Future work is required to obtain more precisely effects of heat stress on the relative ADFI and ADG based on the future genetically modifications.

\section{ACKNOWLEDGEMENT}

This work was supported by Grant No. PJ014485032019 from Rural Development Administration, Republic of Korea; and the 2019 RDA Fellowship Program of the Rural Development Administration, Republic of Korea.

\section{REFERENCES}

Cervantes, M, D. Antoine, J.A.Valle, N. Vásquez, R.L. Camacho, H. Bernal and A. Morales. 2018. Effect of feed intake level on the body temperature of pigs exposed to heat stress conditions. J Therm Biol. 76:1-7.

Collin, A., J. van Milgen, S. Dubois and J. Noblet. 2001. Effect of high temperature on feeding behaviour and heat production in grouphoused young pig. Br. J. Nutr. 86(1):63-70.

Cottrell, J.J., F. Liu, A.T. Hung, K. DiGiacomo, S.S. Chauhan, B.J. Leury, J.B. Furness, P. Celi and F.R. Dunshea. 2015. Nutritional strategies to alleviate heat stress in pigs. Anim. Prod. Sci. 55(12):1391-1402.

Ghassemi Nejad, J., J.D. Lohakare, J.W. West, B.W. Kim, B.H Lee and K.I Sung. 2015. Effects of water restriction following feeding on nutrient digestibilities, milk yield and composition and blood hormones in lactating Holstein cows under heat stress conditions. Ital. J. Anim. Sci. 14:3952.

Hermesch, S., L. Li, A.B. Doeschl-Wilson and H. Gilbert. 2015. Selection for productivity and robustness traits in pigs. Anim. Prod. Sci. 55(12):1437-1447.

Hyun Y., M. Ellis, G. Riskowski and R.W. Johnson. 1998. Growth performance of pigs subjected to multiple concurrent environmental stressors. J. Anim. Sci. 76(3):721-727.

Johnson, J.S., M.V. Sanz Fernandez, J.F. Patience, J.W. Ross, N.K. Gabler, M.C. Lucy, T.J. Safranski, R.P. Rhoads and L.H. Baumgard. 
2015. Effects of in utero heat stress on postnatal body composition in pigs: II. Finishing phase. J. Anim. Sci. 93(1):82-92

Le Dividich, J., J. Noblet, P. Herpin, J. van Milgen and N. Quiniou. 1998. Thermoregulation. In Progress in Pig Science. Wiseman J, Varley MA., Chadwick JP, ed. Nottingham Univ. Press, Nottingham, UK.

Mayorga, E.J., D. Renaudeau, B.C. Ramirez, J.W. Ross and L.H. Baumgard. 2018. Heat stress adaptations in pigs. Animal. Front. (Pubished online).

[NRC] Nutrient Requirements of Swine. 2012. 11 th rev ed. Washington, DC, USA: National Research Council, National Academy Press.

Nienaber, J.A., G.L. Hahn, R.A. Eigenberg, R.L. Kortals, J.T. Yen and D.L. Harris. 1997. Genetic and heat stress interaction effects on finishing swine. Pages 1017-1023 in ASAE Meeting, Bloomington, MN.

Noblet, J., C. Karege, S. Dubois and J. van Milgen. 1999. Metabolic utilization of energy and maintenance requirements in growing pigs: Effects of sex and genotype. J. Anim. Sci. 77(5):1208-1216.

Pearce, S.C., M.V. Sanz-Fernandez, J.H. Hollis,
L.H. Baumgard and N.K. Gabler. 2014. Short-term exposure to heat stress attenuates appetite and intestinal integrity in growing pigs. J. Anim. Sci. 92(12):5444-5454.

Pearce, S.C., S.M. Lonergan, E. Huff-Lonergan, L.H. Baumgard and N.K. Gabler. 2015. Acute heat stress and reduced nutrient intake alter intestinal proteomic profile and gene expression in pigs. PloS one. 10(11)p.e0143099.

$\mathrm{R}$ Core Team. 2013. R: A language and environment for statistical computing. $\mathrm{R}$ Foundation for Statistical Computing, Vienna, Austria.

Renaudeau D, J.L. Gourdine and N.R. St-Pierre. 2011. A meta-analysis of the effects of high ambient temperature on growth performance of growing-finishing pigs. J. Anim. Sci. 89(7):2220-2230.

Santos, L.S.D., C. Pomar, P.H.R.F. Campos, W.C.D. Silva, J.D.P. Gobi, A.M. Veira, A.Z. Fraga and L. Hauschild. 2018. Precision feeding strategy for growing pigs under heat stress conditions. J. Anim. Sci. 96(11):47894801 